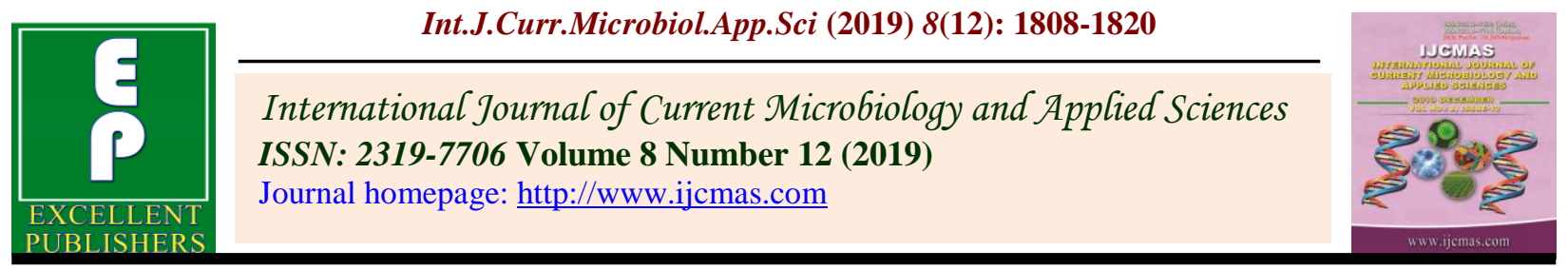

Original Research Article

https://doi.org/10.20546/ijcmas.2019.812.217

\title{
Socio-Economic Impact of Mahatma Gandhi National Rural Employment Guarantee on its Beneficiaries in Marathwada Region, India
}

\author{
V. G. Dhulgand ${ }^{1 *}$ and R. P. Kadam ${ }^{2}$ \\ Department of Extension Education, Vasantrao Naik Marathwada Krishi Vidyapeeth \\ (VNMKV), Parbhani (M. S.), India \\ *Corresponding author
}

\section{A B S T R A C T}

\section{Keywords}

Socio-economic impact,

MGNREGA

beneficiaries

\section{Article Info}

Accepted:

15 November 2019

Available Online:

10 December 2019
The present study was conducted purposively in Aurangabad, Nanded, Beed and Jalna district of the Marathwada region of Maharashtra state during the year 2017-2018. From this four districts eight tahsils were selected purposively. From each selected taluka two villages were selected purposively for the study. Fifteen (15) beneficiaries of MGNREGA were selected randomly from each selected villages. Thus comprising total 240 beneficiaries were selected from Marathwada region for research study. For measuring socio-economic impact of MGNREGA on its beneficiaries scale developed and used for assessment of socio-economic impact if MGNREGA. It was found that, 77.08 per cent educational change after participation of MGNREGA in medium category, 55.42 per cent of beneficiaries of MGNREGA in medium occupational change category, 72.50 per cent of MGNREGA beneficiaries had medium annual income change category, 66.25 per cent of MGNREGA beneficiaries had medium saving pattern change category, 67.50 per cent of MGNREGA beneficiaries had medium level of expenditure change category, 67.92 per cent of MGNREGA beneficiaries had medium level of material possession change, 58.75 per cent of MGNREGA beneficiaries had medium level of socio-political participation change, 66.67 per cent of MGNREGA had medium level of employment generation change after participation of MGNREGA scheme. It was observed that, majority $(51.25 \%)$ MGNREGA beneficiaries had medium level of overall impact of MGNREGA.

\section{Introduction}

Poverty and unemployment are the twin problem faced by the developing countries. According to the planning commission of India nearly $29.8 \%$ population is Below Poverty Line (BPL). Policy makers in India have realized the need for generating employment opportunities on large scale to bring the teeming millions of population above poverty line (APL). While the labour force in India is increasing in numbers at every year. Majority of population (72.22 per cent) live in rural areas and many of them suffer owing to seasonal unemployment, under employment and disguised unemployment. (Source: Planning Commission). In India, GDP and Unemployment rates are going hand 
in hand, causing fret for any democratic society. Unemployment and poverty are strongly related and hinder the economic growth and development of the country.

In India, these two problems are severe in rural areas, leaving it outside the growth path. Thus, Government of India aiming at balanced growth and to overcome above mentioned weaknesses of past employment programmes, passed National Rural Employment Guarantee Act (NREGA) in 25 August 2005 in order to empower the rural labourers with right to get employment of 100 days per year per household during off-season.

In accordance, National Rural Employment Guarantee Act has been launched in Anantapur district of Andhra Pradesh on $2^{\text {nd }}$ February, 2006, with effect from $1^{\text {st }}$ April 2006 in 200 drought prone and backward districts in India. This was extended to additional 130 districts in the financial year 2007-2008. The NREGA coverage has been expanded from 330 districts to 619 districts of India beginning April, 2008. In Maharashtra the NREGA was implemented during the 2006 in 12 districts (Dhule, Nandurbar, Ahemednagar, Aurangabad, Hingoli, Nanded, Amravati, Gadchiroli, Yavatmal, Bhandara, Gondhiya and Chjandrapur) of Maharashtra state.

Thus NREGA covered that entire country with the exception of districts that have a hundred percent urban population. This programme has been formulated by merging early formulated programmes such as Sampoorna Gramin Rozgar Yojana (SGRY) of 2001 and National Food for Work Programme (NFFWP) of 2004. Again the Government of India on $2^{\text {nd }}$ October, 2009 renamed its flagship rural job guarantee programme- National Rural Employment Guarantee Act (NREGA) as Mahatma Gandhi National Rural Employment Guarantee Act (MGNREGA).

\section{Materials and Methods}

The present study was conducted purposively in Aurangabad, Nanded, Beed and Jalna district of the Marathwada region of Maharashtra state during the year 2017-2018. Selected district eight tahsils were selected purposively. From each selected taluka two villages were selected purposively for the study. Fifteen (15) beneficiaries of MGNREGA were selected randomly from each selected villages. Thus comprising total 240 beneficiaries were selected from Marathwada region for research study. For measuring socio-economic impact of MGNREGA on its beneficiaries scale development and used for assessment of socio-economic impact of MGNREGA. Expost facto research design was adopted in this study. The data were collected with the help of pretested interview schedule. The statistical methods and tests such as frequency, percentage, mean, standard deviation and ' $Z$ ' test were used for the analysis of data.

\section{Results and Discussion}

Socio-economic impact of MGNREGA on its beneficiaries

\section{Educational change impact}

It was observed from the Table 1 that, nearly three fourth $(73.75 \%)$ of the beneficiaries had in medium educational change categories, followed by 20.83 per cent of them in high and 5.42 per cent of them were in low educational change category before participation of MGNREGA scheme.

After participation of MGNREGA scheme, more than three fourth $(77.08 \%)$ of the MGNREGA beneficiaries had in medium educational change categories, followed by 16.25 per cent of them in high and 6.67 per cent of them were in low educational change 
category. Education of children was given prime importance by the MGNREGA beneficiaries and significant portion of additional income spent on it. According to MGNREGA beneficiaries in study area, the drop out ratio was substantially reduced since participation of MGNREGA scheme as an additional source of income to beneficiaries families. So most of the MGNREGA beneficiaries provided educational facilities to their children.

Calculated ' $Z$ ' value 3.51 from Table 1 was found significant at 1 per cent level of probability indicating that there existed a significant difference in educational change of children of MGNREGA beneficiaries before and after participation of MGNREGA scheme. It could therefore, be stated that the MGNREGA beneficiaries differed significantly in education before and after participation of MGNREGA scheme.

It was observed from the Table 2 that, after participation of MGNREGA scheme, nearly three fourth $(73.75 \%)$ of MGNREGA beneficiaries had medium educational change category, followed by 13.75 per cent of them were in high and 12.50 per cent of the beneficiaries had low educational change category. It was observed from above table that, most of the MGNREGA beneficiaries having medium impact of MGNREGA on educational change.

\section{Occupational change impact}

It was observed from the Table 3 that, more than half $(50.84 \%)$ of the beneficiaries had in medium occupational change categories, followed by 30.83 per cent of them in low and 18.33 per cent of them were in high occupational change category before participation of MGNREGA scheme. After participation of MGNREGA scheme, more than half $(55.42 \%)$ of the beneficiaries had in medium occupational change categories, followed by 26.67 per cent of them in high and 17.91 per cent of them were in low occupational change category.

This shift of beneficiaries of MGNREGA scheme to additional occupation of MGNREGA beneficiaries. It was observed from the above table that, drastic occupational changes observed after participation of MGNREGA scheme.

Calculated ' $Z$ ' value 2.23 from Table 3 was found significant at 5 per cent level of probability indicating that there existed a significant difference in occupational change of MGNREGA beneficiaries before and after participation of MGNREGA scheme. It could therefore; it is observed that the MGNREGA beneficiaries differed significantly in their occupation before and after participation of MGNREGA scheme.

It was observed from the Table 4 that, after participation of MGNREGA scheme, two third $(68.75 \%)$ of beneficiaries had medium occupational change category, followed by 22.50 per cent of them were in high and 8.75 per cent of the MGNREGA beneficiaries had low occupational change category. It was observed from above table that, most of the MGNREGA beneficiaries having medium impact of MGNREGA on occupational change.

\section{Annual income change}

It was observed from the Table 5 that, more than half $(62.50 \%)$ of the beneficiaries had in medium annual income change categories, followed by 21.25 per cent of them in low and 16.25 per cent of them were in high annual income change category before participation of MGNREGA scheme. After participation of MGNREGA scheme, nearly three fourth $(72.50 \%)$ of the MGNREGA beneficiaries had 
in medium annual income change categories, followed by 21.67 per cent of them in high and 5.83 per cent of them were in low annual income change category. It could be concluded that before participation of MGNREGA scheme, the main source of beneficiaries from traditional crop cultivation like cereals, fodder etc. However, total income of the beneficiaries was not enough to meet their basic needs and hence there was no scope for saving and sometimes they had to borrow to maintain their routine life.

After participation of MGNREGA, additional employment generated by MGNREGA scheme had made significant changes in the annual per capita income of the MGNREGA beneficiaries. It was observed from the above table that, drastic annual income changes observed after participation of MGNREGA scheme.

Calculated ' $Z$ ' value 3.17 from Table 5 was found significant at 1 per cent level of probability indicating that there existed a significant difference in annual income change of MGNREGA beneficiaries before and after participation of MGNREGA scheme. It could therefore, be stated that the MGNREGA beneficiaries differed significantly in their annual income before and after participation of MGNREGA scheme. It means that MGNREGA scheme is helpful to the beneficiaries for increase annual income.

It was observed from the Table 6 that, after participation of MGNREGA scheme, more than two third $(68.76 \%)$ per cent of MGNREGA beneficiaries had medium annual income change category, followed by 22.08 per cent of them were in high and 9.16 per cent of the beneficiaries had low annual income change category. It was observed from above table that, most of the MGNREGA beneficiaries having medium impact of MGNREGA on annual income change.

\section{Saving pattern change}

It was observed from the Table 7 that, More than half $(53.75 \%)$ of the beneficiaries had in medium saving pattern change categories, followed by 28.75 per cent and 17.50 per cent of them were in low and high saving pattern change category respectively before participation of MGNREGA scheme.

After participation of MGNREGA scheme, more than two third $(66.25 \%)$ of the beneficiaries had in medium saving pattern change categories and 17.92 per cent of them in high saving pattern change category and 15.83 per cent of the MGNREGA beneficiaries from low saving pattern change category. It could be concluded that, before participation of MGNREGA scheme total income of the beneficiaries was not enough to meet their basic needs and hence there was no scope for saving and sometimes they had to borrow to maintain their routine life.

This shift of beneficiaries of MGNREGA scheme to increase saving pattern after participation of MGNREGA might be due to the increase in annual income and change in education of their children due to employment generation. It was observed from the above table that, drastic saving pattern changes observed after participation of MGNREGA scheme.

Calculated ' $Z$ ' value 4.15 from Table 7 was found significant at 1 per cent level of probability indicating that there existed a significant difference in saving pattern change of MGNREGA beneficiaries before and after participation of MGNREGA scheme. It could therefore, be stated that the MGNREGA beneficiaries differed significantly in their annual income before and after participation of MGNREGA scheme. It means that MGNREGA scheme is helpful to the beneficiaries for increase their saving pattern. 
It was observed from the Table 8 that, after participation of MGNREGA scheme, more than two third $(66.25 \%)$ of MGNREGA beneficiaries had medium saving pattern change category, followed by 17.08 per cent and 16.67 per cent of the MGNREGA beneficiaries had high and low saving pattern change category respectively. It was observed from above table that, most of the MGNREGA beneficiaries having medium impact of MGNREGA on saving pattern change.

\section{Expenditure change}

It was observed from the Table 9 that, more than half $(54.17 \%)$ of the MGNREGA beneficiaries had in medium expenditure change categories, followed by 28.75 per cent and 17.08 per cent of them were in low and high expenditure change category respectively before participation of MGNREGA scheme.

After participation of MGNREGA scheme, more than two third $(67.50 \%)$ of the MGNREGA beneficiaries had in medium expenditure change categories, followed by 20.83 per cent and 11.67 per cent of them were in high and low expenditure change category respectively. It could be concluded that, before participation of MGNREGA scheme total income of the beneficiaries was not enough to expend on their basic needs of daily life. This change of beneficiaries of MGNREGA to increase investment on expenditure after participation of MGNREGA might be due to the increase in income due to employment generation. It was observed from the above table that, drastic expenditure changes observed after participation of MGNREGA scheme.

Calculated ' $Z$ ' value 4.20 from Table 9 was found significant at 1 per cent level of probability indicating that there existed a significant difference in expenditure change of
MGNREGA beneficiaries before and after participation of MGNREGA scheme. It could therefore, be stated that the MGNREGA beneficiaries differed significantly in their expenditure change before and after participation of MGNREGA scheme. It means that MGNREGA scheme helpful to the beneficiaries for increase their expenditure change.

It was observed from the Table 10 that, after participation of MGNREGA scheme, more than two third $(66.67 \%)$ of MGNREGA beneficiaries had medium expenditure change category, followed by 17.08 per cent and 16.25 per cent of the beneficiaries had high and low expenditure change category respectively. It was observed from above table that, most of the beneficiaries having medium impact of MGNREGA on expenditure change.

\section{Material possession change}

It was observed from the Table 11 that, more than half $(56.66 \%)$ of the beneficiaries had in medium material possession change categories, followed by 28.34 per cent in low and 15.00 per cent of them were in high material possession change category before participation of MGNREGA scheme.

After participation of MGNREGA scheme, more than two third $(67.92 \%)$ of the beneficiaries had in medium material possession change categories, followed by 17.08 per cent and 15.00 per cent of them in from high and low material possession change category respectively. In material possession there was observed that before participation of MGNREGA scheme, beneficiaries had lack of luxurious facility, assets like black and white T.V, Radio, Bullock car, bicycle due to their low annual income but result showed that after participation of MGNREGA scheme, there was change in their life like luxuries facility like colore T.V., electricity facility, livestock, 
mobile, motor cycle and their housing pattern which improve their standard of living of their life. This increase of material possession of beneficiaries of MGNREGA scheme after participation of MGNREGA scheme might be due to the increase in income of beneficiaries of MGNREGA scheme due to employment generation. It was observed from the above table that, drastic material possession changes observed after participation of MGNREGA scheme.

Calculated ' $Z$ ' value 2.26 from Table 11 was found significant at 5 per cent level of probability indicating that there existed a significant difference in material possession change of MGNREGA beneficiaries before and after participation of MGNREGA scheme. It could therefore, be stated that the MGNREGA beneficiaries differed significantly in their material possession change before and after participation of MGNREGA scheme. It means that MGNREGA scheme helpful to the beneficiaries for increase their material possession change.

It was observed from the Table 12 that, after participation of MGNREGA scheme, majority $(70.00 \%)$ of beneficiaries had medium material possession change category, followed by 22.50 per cent and 7.50 of the MGNREGA beneficiaries had high and low material possession change category respectively. It was observed from above table that, most of the MGNREGA beneficiaries having medium impact of MGNREGA on material possession change.

\section{Socio-political participation change}

It was observed from the Table 13 that, more than half $(55.41 \%)$ of the beneficiaries had in medium socio-political participation change categories, followed by 28.75 per cent and 15.84 per cent of them were in low and high socio-political participation change category respectively before participation of MGNREGA scheme.

After participation of MGNREGA scheme, more than half $(58.75 \%)$ of the beneficiaries had in medium socio-political participation change categories, followed by 24.59 per cent and 16.66 per cent of them in from high and low socio-political participation change category respectively. Before participation of MGNREGA scheme there was no any contact of beneficiaries to social organization like Gram Panchayat, Panchayat Samiti, Zilla Parishad or any political party. This shift of beneficiaries of MGNREGA scheme due to participation of MGNREGA beneficiaries in different social programmes, social activities like Krushi Melawas, social campaign the participation of MGNREGA beneficiaries in various social organization like Gram Panchayat, Panchayat Samiti, Zilla Parishad or any political party was increased due to MGNREGA scheme. It was observed from the above table that, drastic socio-political participation changes observed after participation of MGNREGA scheme.

Calculated ' $Z$ ' value 2.29 from Table 13 was found significant at 5 per cent level of probability indicating that there existed a significant difference in socio-political participation change of beneficiaries before and after participation of MGNREGA scheme. It could therefore, be stated that the MGNREGA beneficiaries differed significantly in their socio-political participation change before and after participation of MGNREGA scheme. It means that MGNREGA scheme is helpful to the beneficiaries for increase their socio-political participation change.

It was observed from the Table 14 that, after participation of MGNREGA scheme, nearly two third $(64.17 \%)$ of beneficiaries had 
medium socio-political participation change, category followed by 26.66 per cent and 9.17 per cent of the MGNREGA beneficiaries had high and low socio-political participation change category. It was observed from above table that, most of the MGNREGA beneficiaries having medium impact of MGNREGA on socio-political participation change.

\section{Employment generation change}

It was observed from the Table 15 that, more than half $(61.25 \%)$ of the beneficiaries had in medium employment generation change categories, followed by 25.83 per cent and 12.92 per cent of them were in low and high employment generation change category respectively before participation of MGNREGA scheme.

After participation of MGNREGA scheme, more than two third $(66.67 \%)$ of the MGNREGA beneficiaries had in medium employment generation change categories, followed by 17.50 per cent and 15.83 per cent of them in from high and low employment generation change category respectively. The mean employment available for MGNREGA beneficiaries before participation and after participation of MGNREGA. This increase of employment might be due to policy initiative and enhanced fund allocation by the Central Government. It was observed from the above table that, drastic employment generation changes observed after participation of MGNREGA scheme.

Calculated ' $Z$ ' value 2.64 from Table 15 was found significant at 1 per cent level of probability indicating that there existed a significant difference in employment generation change of MGNREGA beneficiaries before and after participation of MGNREGA scheme. It could therefore, be stated that the MGNREGA beneficiaries differed significantly in their employment generation change before and after participation of MGNREGA scheme. It means that MGNREGA scheme is helpful to the beneficiaries for increase their employment generation change.

It was observed from the Table 16 that, after participation of MGNREGA scheme, more than two third $(70.41 \%)$ of beneficiaries had medium employment generation change category, followed by 25.00 per cent and 4.59 per cent of the MGNREGA beneficiaries had high and low employment generation change category respectively. It was observed from above table that, most of the beneficiaries having medium impact of MGNREGA on employment generation change.

Table.1 Distribution of the MGNREGA beneficiaries according to their educational change before and after participation of MGNREGA scheme

\begin{tabular}{|c|c|c|c|c|c|c|c|c|}
\hline \multirow[t]{2}{*}{$\begin{array}{l}\text { Sr. } \\
\text { No. }\end{array}$} & \multirow[t]{2}{*}{ Category } & \multirow[t]{2}{*}{ Score } & \multicolumn{2}{|c|}{$\begin{array}{c}\text { Before } \\
\text { participation } \\
(\mathbf{n}=\mathbf{2 4 0})\end{array}$} & \multirow[t]{2}{*}{ Score } & \multicolumn{2}{|c|}{$\begin{array}{c}\text { After } \\
\text { participation } \\
(\mathbf{n}=\mathbf{2 4 0})\end{array}$} & 'Z' value \\
\hline & & & No. & $\%$ & & No. & $\%$ & \multirow[t]{7}{*}{$03.51 * *$} \\
\hline 1. & Low & Up to 8 & 13 & 05.42 & Up to 11 & 16 & 06.67 & \\
\hline 2. & Medium & 9 to 10 & 177 & 73.75 & 12 to 13 & 185 & 77.08 & \\
\hline 3. & High & $11 \&$ above & 50 & 20.83 & $14 \&$ above & 39 & 16.25 & \\
\hline & & Total & 240 & 100 & Total & 240 & 100 & \\
\hline & & Mean & \multicolumn{2}{|c|}{8.64} & Mean & \multicolumn{2}{|c|}{12.05} & \\
\hline & & S.D. & \multicolumn{2}{|c|}{0.98} & S.D. & \multicolumn{2}{|c|}{1.11} & \\
\hline
\end{tabular}

** Significant at 0.01 level of probability 
Table.2 Distribution of the MGNREGA beneficiaries according to their impact of MGNREGA on educational change

\begin{tabular}{|c|c|c|c|c|}
\hline Sr. No. & Category & Score & \multicolumn{2}{|c|}{ Beneficiaries (n=240) } \\
\cline { 3 - 5 } & & & Number & Percentage \\
\hline 1. & Low & Up to 2 & 30 & 12.50 \\
\hline 2. & Medium & 3 to 4 & 33 & 73.75 \\
\hline 3. & High & 5 \& above & \multicolumn{2}{c|}{ S.D. $=\mathbf{1 . 0 1}$} \\
\hline
\end{tabular}

Table.3 Distribution of the MGNREGA beneficiaries according to their occupational change before and after participation of MGNREGA scheme

\begin{tabular}{|c|c|c|c|c|c|c|c|c|}
\hline \multirow[t]{2}{*}{$\begin{array}{l}\text { Sr. } \\
\text { No. }\end{array}$} & \multirow[t]{2}{*}{ Category } & \multirow[t]{2}{*}{ Score } & \multicolumn{2}{|c|}{$\begin{array}{c}\text { Before } \\
\text { participation } \\
(\mathbf{n}=\mathbf{2 4 0})\end{array}$} & \multirow[t]{2}{*}{ Score } & \multicolumn{2}{|c|}{$\begin{array}{c}\text { After } \\
\text { participation } \\
(\mathbf{n}=\mathbf{2 4 0})\end{array}$} & ' $Z$ ' value \\
\hline & & & No. & $\%$ & & No. & $\%$ & \multirow[t]{7}{*}{ 02.23* } \\
\hline 1. & Low & Up to 6 & 74 & 30.83 & Up to 8 & 43 & 17.91 & \\
\hline 2. & Medium & 7 to 8 & 122 & 50.84 & 9 to 10 & 133 & 55.42 & \\
\hline 3. & High & $9 \&$ above & 44 & 18.33 & $\begin{array}{c}11 \& \\
\text { above }\end{array}$ & 64 & 26.67 & \\
\hline & & Total & 240 & 100 & Total & 240 & 100 & \\
\hline & & Mean & \multicolumn{2}{|c|}{7.13} & Mean & \multicolumn{2}{|c|}{9.20} & \\
\hline & & S.D. & \multicolumn{2}{|c|}{1.32} & S.D. & \multicolumn{2}{|c|}{1.10} & \\
\hline
\end{tabular}

* Significant at 0.01 level of probability

Table.4 Distribution of the MGNREGA beneficiaries according to their impact of MGNREGA on occupational change

\begin{tabular}{|c|c|c|c|c|}
\hline Sr. No. & Category & \multirow{2}{*}{ Score } & \multicolumn{2}{|c|}{ Beneficiaries (n=240) } \\
\cline { 3 - 5 } & & & Number & Percentage \\
\hline 1. & Low & Up to 1 & 21 & 08.75 \\
\hline 2. & Medium & 2 to 3 & 165 & 68.75 \\
\hline 3. & High & 4 \& above & 54 & 22.50 \\
\hline \multicolumn{2}{r|}{ Mean $=\mathbf{5 . 0 1}$} & & \multicolumn{2}{|c|}{ S.D. = 1.94 } \\
\hline
\end{tabular}


Table.5 Distribution of the MGNREGA beneficiaries according to their annual income change before and after participation of MGNREGA scheme

\begin{tabular}{|c|c|c|c|c|c|c|c|c|}
\hline \multirow[t]{2}{*}{$\begin{array}{l}\text { Sr. } \\
\text { No. }\end{array}$} & \multirow[t]{2}{*}{ Category } & \multirow[t]{2}{*}{ Score } & \multicolumn{2}{|c|}{$\begin{array}{c}\text { Before } \\
\text { participation } \\
(\mathbf{n}=\mathbf{2 4 0})\end{array}$} & \multirow[t]{2}{*}{ Score } & \multicolumn{2}{|c|}{$\begin{array}{c}\text { After } \\
\text { participation } \\
(\mathbf{n}=\mathbf{2 4 0})\end{array}$} & 'Z' value \\
\hline & & & No. & $\%$ & & No. & $\%$ & \multirow[t]{7}{*}{ 03.17** } \\
\hline 1. & Low & Up to 7 & 51 & 21.25 & Up to 12 & 14 & 05.83 & \\
\hline 2. & Medium & 8 to 9 & 150 & 62.50 & 13 to 14 & 174 & 72.50 & \\
\hline 3. & High & $\begin{array}{c}10 \& \\
\text { above }\end{array}$ & 39 & 16.25 & $\begin{array}{c}15 \& \\
\text { above }\end{array}$ & 52 & 21.67 & \\
\hline & & Total & 240 & 100 & Total & 240 & 100 & \\
\hline & & Mean & \multicolumn{2}{|c|}{8.46} & Mean & \multicolumn{2}{|c|}{13.10} & \\
\hline & & S.D. & \multicolumn{2}{|c|}{1.75} & S.D. & \multicolumn{2}{|c|}{1.43} & \\
\hline
\end{tabular}

** Significant at 0.01 level of probability

Table.6 Distribution of the MGNREGA beneficiaries according to their impact of MGNREGA on annual income change

\begin{tabular}{|c|c|c|c|c|}
\hline \multirow[t]{2}{*}{ Sr. No. } & \multirow[t]{2}{*}{ Category } & \multirow[t]{2}{*}{ Score } & \multicolumn{2}{|c|}{ Beneficiaries $(n=240)$} \\
\hline & & & Number & Percentage \\
\hline 1. & Low & Up to 3 & 22 & 09.16 \\
\hline 2. & Medium & 4 to 5 & 165 & 68.76 \\
\hline 3. & High & $6 \&$ above & 53 & 22.08 \\
\hline & \multicolumn{2}{|c|}{ Mean $=4.64$} & \multicolumn{2}{|c|}{ S.D. $=1.35$} \\
\hline
\end{tabular}

Table.7 Distribution of the MGNREGA beneficiaries according to their saving pattern change before and after participation of MGNREGA scheme

\begin{tabular}{|c|c|c|c|c|c|c|c|c|}
\hline \multirow[t]{2}{*}{$\begin{array}{l}\text { Sr. } \\
\text { No. }\end{array}$} & \multirow[t]{2}{*}{ Category } & \multirow[t]{2}{*}{ Score } & \multicolumn{2}{|c|}{$\begin{array}{c}\text { Before } \\
\text { participation } \\
(\mathbf{n}=\mathbf{2 4 0})\end{array}$} & \multirow[t]{2}{*}{ Score } & \multicolumn{2}{|c|}{$\begin{array}{c}\text { After } \\
\text { participation } \\
(n=\mathbf{2 4 0})\end{array}$} & ' $Z$ ' value \\
\hline & & & No. & $\%$ & & No. & $\%$ & \multirow[t]{7}{*}{$04.15 * *$} \\
\hline 1. & Low & Up to 4 & 69 & 28.75 & Up to 12 & 38 & 15.83 & \\
\hline 2. & Medium & 5 to 6 & 129 & 53.75 & 13 to 14 & 159 & 66.25 & \\
\hline \multirow[t]{4}{*}{3.} & High & $7 \&$ above & 42 & 17.50 & $\begin{array}{c}15 \& \\
\text { above }\end{array}$ & 43 & 17.92 & \\
\hline & & Total & 240 & 100 & Total & 240 & 100 & \\
\hline & & Mean & \multicolumn{2}{|c|}{5.16} & Mean & \multicolumn{2}{|c|}{9.40} & \\
\hline & & S.D. & \multicolumn{2}{|c|}{1.28} & S.D. & \multicolumn{2}{|c|}{0.92} & \\
\hline
\end{tabular}

** Significant at 0.01 level of probability 
Table.8 Distribution of the MGNREGA beneficiaries according to their impact of MGNREGA on saving pattern change

\begin{tabular}{|c|c|c|c|c|}
\hline Sr. No. & Category & \multirow{2}{*}{ Score } & \multicolumn{2}{|c|}{ Beneficiaries $(\mathbf{n = 2 4 0})$} \\
\cline { 3 - 5 } & & & Number & Percentage \\
\hline 1. & Low & Up to 3 & 40 & 16.67 \\
\hline 2. & Medium & 4 to 5 & 159 & 66.25 \\
\hline 3. & High & 6 \& above & 41 & 17.08 \\
\hline \multicolumn{2}{r}{} & \multicolumn{2}{|c|}{ S.D. $=\mathbf{1 . 2 3}$} \\
\hline
\end{tabular}

Table.9 Distribution of the MGNREGA beneficiaries according to their expenditure change before and after participation of MGNREGA scheme

\begin{tabular}{|c|c|c|c|c|c|c|c|c|}
\hline \multirow[t]{2}{*}{$\begin{array}{l}\text { Sr. } \\
\text { No. }\end{array}$} & \multirow[t]{2}{*}{ Category } & \multirow[t]{2}{*}{ Score } & \multicolumn{2}{|c|}{$\begin{array}{c}\text { Before } \\
\text { participation } \\
(\mathbf{n}=\mathbf{2 4 0})\end{array}$} & \multirow[t]{2}{*}{ Score } & \multicolumn{2}{|c|}{$\begin{array}{c}\text { After } \\
\text { participation } \\
(\mathbf{n}=\mathbf{2 4 0})\end{array}$} & ' $Z$ ' value \\
\hline & & & No. & $\%$ & & No. & $\%$ & \multirow[t]{7}{*}{$04.20 * *$} \\
\hline 1. & Low & Up to 4 & 69 & 28.75 & Up to 8 & 28 & 11.67 & \\
\hline 2. & Medium & 5 to 6 & 130 & 54.17 & 9 to 10 & 162 & 67.50 & \\
\hline 3. & High & $7 \&$ above & 41 & 17.08 & $\begin{array}{c}11 \& \\
\text { above }\end{array}$ & 50 & 20.83 & \\
\hline & & Total & 240 & 100 & Total & 240 & 100 & \\
\hline & & Mean & \multicolumn{2}{|c|}{5.15} & Mean & \multicolumn{2}{|c|}{9.38} & \\
\hline & & S.D. & \multicolumn{2}{|c|}{1.28} & S.D. & \multicolumn{2}{|c|}{0.89} & \\
\hline
\end{tabular}

** Significant at 0.01 level of probability

Table.10 Distribution of the MGNREGA beneficiaries according to their impact of MGNREGA on expenditure change

\begin{tabular}{|c|c|c|c|c|}
\hline Sr. No. & Category & Score & \multicolumn{2}{|c|}{ Beneficiaries $(\mathbf{n = 2 4 0})$} \\
\cline { 3 - 5 } & & & Number & Percentage \\
\hline 1. & Low & Up to 3 & 39 & 16.25 \\
\hline 2. & Medium & 4 to 5 & 160 & 66.67 \\
\hline 3. & High & \& above & 41 & 17.08 \\
\hline \multicolumn{2}{r|}{ Mean $=\mathbf{4 . 2 3}$} & \multicolumn{2}{|c|}{ S.D. $=\mathbf{1 . 2 5}$} \\
\hline
\end{tabular}


Table.11 Distribution of the MGNREGA beneficiaries according to their material possession change before and after participation of MGNREGA scheme

\begin{tabular}{|c|c|c|c|c|c|c|c|c|}
\hline \multirow[t]{2}{*}{$\begin{array}{l}\text { Sr. } \\
\text { No. }\end{array}$} & \multirow[t]{2}{*}{ Category } & \multirow[t]{2}{*}{ Score } & \multicolumn{2}{|c|}{$\begin{array}{c}\text { Before } \\
\text { participation } \\
(\mathbf{n}=\mathbf{2 4 0})\end{array}$} & \multirow[t]{2}{*}{ Score } & \multicolumn{2}{|c|}{$\begin{array}{c}\text { After } \\
\text { participation } \\
(\mathbf{n}=\mathbf{2 4 0})\end{array}$} & ' $Z$ ' value \\
\hline & & & No. & $\%$ & & No. & $\%$ & \multirow[t]{7}{*}{ 02.26* } \\
\hline 1. & Low & Up to 6 & 68 & 28.34 & Up to 8 & 36 & 15.00 & \\
\hline 2. & Medium & 7 to 8 & 136 & 56.66 & 9 to 10 & 163 & 67.92 & \\
\hline 3. & High & $9 \&$ above & 36 & 15.00 & $\begin{array}{c}11 \& \\
\text { above }\end{array}$ & 41 & 17.08 & \\
\hline & & Total & 240 & 100 & Total & 240 & 100 & \\
\hline & & Mean & \multicolumn{2}{|c|}{7.12} & Mean & \multicolumn{2}{|c|}{9.16} & \\
\hline & & S.D. & \multicolumn{2}{|c|}{1.33} & S.D. & \multicolumn{2}{|c|}{1.08} & \\
\hline
\end{tabular}

** Significant at 0.01 level of probability

Table.12 Distribution of the MGNREGA beneficiaries according to their impact of MGNREGA on material possession change

\begin{tabular}{|c|c|c|c|c|}
\hline Sr. No. & Category & \multirow{2}{*}{ Score } & \multicolumn{2}{|c|}{ Beneficiaries (n=240) } \\
\cline { 3 - 5 } & & & Number & Percentage \\
\hline $\mathbf{1 .}$ & Low & Up to 1 & 18 & 07.50 \\
\hline $\mathbf{2 .}$ & Medium & 2 to 3 & 168 & 70.00 \\
\hline $\mathbf{3 .}$ & High & 4 \& above & 54 & 22.50 \\
\hline & Mean $=\mathbf{2 . 0 3}$ & & \multicolumn{2}{|c|}{ S.D. $=\mathbf{1 . 0 0}$} \\
\hline
\end{tabular}

Table.13 Distribution of the MGNREGA beneficiaries according to their socio-political participation change before and after participation of MGNREGA scheme

\begin{tabular}{|c|c|c|c|c|c|c|c|c|}
\hline \multirow[t]{2}{*}{$\begin{array}{l}\text { Sr. } \\
\text { No. }\end{array}$} & \multirow[t]{2}{*}{ Category } & \multirow[t]{2}{*}{ Score } & \multicolumn{2}{|c|}{$\begin{array}{c}\text { Before } \\
\text { participation } \\
(\mathbf{n}=\mathbf{2 4 0})\end{array}$} & \multirow[t]{2}{*}{ Score } & \multicolumn{2}{|c|}{$\begin{array}{c}\text { After } \\
\text { participation } \\
(\mathbf{n}=\mathbf{2 4 0})\end{array}$} & 'Z' value \\
\hline & & & No. & $\%$ & & No. & $\%$ & \multirow[t]{7}{*}{ 02.29* } \\
\hline 1. & Low & Up to 6 & 69 & 28.75 & Up to 9 & 40 & 16.66 & \\
\hline 2. & Medium & 7 to 8 & 133 & 55.41 & 10 to 11 & 141 & 58.75 & \\
\hline 3. & High & $9 \&$ above & 38 & 15.84 & $\begin{array}{c}12 \& \\
\text { above }\end{array}$ & 59 & 24.59 & \\
\hline & & Total & 240 & 100 & Total & 240 & 100 & \\
\hline & & Mean & \multicolumn{2}{|c|}{7.18} & Mean & \multicolumn{2}{|c|}{10.23} & \\
\hline & & S.D. & \multicolumn{2}{|c|}{1.49} & S.D. & \multicolumn{2}{|c|}{1.42} & \\
\hline
\end{tabular}

* Significant at 0.05 level of probability 
Table.14 Distribution of the MGNREGA beneficiaries according to their impact of MGNREGA on socio-political participation change

\begin{tabular}{|c|c|c|c|c|}
\hline Sr. No. & Category & Score & \multicolumn{2}{|c|}{ Beneficiaries (n=240) } \\
\cline { 3 - 5 } & & & Number & Percentage \\
\hline 1. & Low & Up to 2 & 22 & 09.17 \\
\hline 2. & Medium & 3 to 4 & 64 & 64.17 \\
\hline 3. & High & 5 \& above & \multicolumn{2}{|c|}{ S.D. $=\mathbf{1 . 0 1}$} \\
\hline
\end{tabular}

Table.15 Distribution of the MGNREGA beneficiaries according to their employment generation change before and after participation of MGNREGA scheme

\begin{tabular}{|c|c|c|c|c|c|c|c|c|}
\hline \multirow[t]{2}{*}{$\begin{array}{l}\text { Sr. } \\
\text { No. }\end{array}$} & \multirow[t]{2}{*}{ Category } & \multirow[t]{2}{*}{ Score } & \multicolumn{2}{|c|}{$\begin{array}{c}\text { Before } \\
\text { participation } \\
(\mathbf{n}=\mathbf{2 4 0})\end{array}$} & \multirow[t]{2}{*}{ Score } & \multicolumn{2}{|c|}{$\begin{array}{c}\text { After } \\
\text { participation } \\
(\mathbf{n}=\mathbf{2 4 0})\end{array}$} & ' $Z$ ' value \\
\hline & & & No. & $\%$ & & No. & $\%$ & \multirow[t]{7}{*}{$02.64 *$} \\
\hline 1. & Low & Up to 7 & 62 & 25.83 & Up to 10 & 38 & 15.83 & \\
\hline 2. & Medium & 8 to 9 & 147 & 61.25 & 11 to 12 & 160 & 66.67 & \\
\hline 3. & High & $\begin{array}{c}10 \& \\
\text { above }\end{array}$ & 31 & 12.92 & $\begin{array}{c}13 \& \\
\text { above }\end{array}$ & 42 & 17.50 & \\
\hline & & Total & 240 & 100 & Total & 240 & 100 & \\
\hline & & Mean & \multicolumn{2}{|c|}{8.18} & Mean & \multicolumn{2}{|c|}{11.26} & \\
\hline & & S.D. & \multicolumn{2}{|c|}{1.25} & S.D. & \multicolumn{2}{|c|}{1.29} & \\
\hline
\end{tabular}

** Significant at 0.01 level of probability

Table.16 Distribution of the MGNREGA beneficiaries according to their impact of MGNREGA on employment generation change

\begin{tabular}{|c|c|c|c|c|}
\hline Sr. No. & Category & \multirow{2}{*}{ Score } & \multicolumn{2}{|c|}{ Beneficiaries $(\mathbf{n}=240)$} \\
\cline { 3 - 5 } & & & Number & Percentage \\
\hline 1. & Low & Up to 2 & 11 & 04.59 \\
\hline 2. & Medium & 3 to 4 & 169 & 70.41 \\
\hline 3. & High & 5 \& above & 60 & 25.00 \\
\hline \multicolumn{2}{|r|}{ Mean $=\mathbf{3 . 0 8}$} & \multicolumn{2}{|c|}{ S.D. $=\mathbf{0 . 9 0}$} \\
\hline
\end{tabular}


Table.17 Distribution of the MGNREGA beneficiaries according to their overall impact of MGNREGA

\begin{tabular}{|c|c|c|c|c|}
\hline \multirow[t]{2}{*}{ Sr. No. } & \multirow[t]{2}{*}{ Category } & \multirow[t]{2}{*}{ Score } & \multicolumn{2}{|c|}{ Beneficiaries $(n=240)$} \\
\hline & & & Number & Percentage \\
\hline 1. & Low & Up to 23 & 42 & 17.50 \\
\hline 2. & Medium & 24 to 27 & 123 & 51.25 \\
\hline 3. & High & $28 \&$ above & 75 & 31.25 \\
\hline & \multicolumn{2}{|c|}{ Mean $=26.75$} & \multicolumn{2}{|c|}{ S.D. $=3.66$} \\
\hline
\end{tabular}

\section{Overall impact}

It was observed from the Table 17 that, after participation of MGNREGA scheme, more than half $(51.25 \%)$ of beneficiaries had medium overall impact, followed by 31.25 per cent and 17.50 per cent of the MGNREGA beneficiaries had high and low overall impact category respectively. It was observed from above table that, most of the beneficiaries having medium overall impact of MGNREGA on its beneficiaries.

Majority of the beneficiaries of MGNREGA had medium level of impact of MGNREGA.

\section{References}

Bhandari, S.D. (2014). Socio-economic impact of Mahatma Gandhi national rural employment guarantee act on the beneficiaries. M.Sc. (Agri.) Thesis, Vasantrao Naik Marathwada Krishi Vidyapeeth, Parbhani (Maharashtra).

Bhosale, J.S. (2014). Impact of integrated pest management technology in cotton on beneficiary farmers of farmers field school. M.Sc. (Agri.) Thesis, Dr. Panjabrao Deshmukh Krishi Vidypeeth,
Akola (Maharashtra).

Garg, S.K., S.K. Badodiya, O.P. Daipuriya and Rawat, U. (2012). Impact of Swarnjayanti Gram Swarozgar Yojna on poverty alleviation in Morar block of Gwalior district. Indian Research Journal of Extension Education (I), pp: 189-191.

Khalache, P.G. and Gaikwad, J.H. (2011). Impact of watershed development programme of watershed organization trust (WOTR) on the beneficiaries in Ahmednagar district. Indian Journal of Extension Education (47), No. 3 \& 4, pp: 104-108.

Khandave, S.R. and Suryawanshi P.S. (2015). Impact of National Horticulture Mission on beneficiaries. J. Agric. Res. Technol. 40 (2), pp: 348-350.

Mankar, D.M., P.P. Wankhade and Kale, N.M. (2014). Socio-economic impact of improved Soybean technology on farmers. International J. Exten. Edu. (10), pp: 146-152.

Mankar, D.M., P.P. Wankhade and Shambharkar, Y.B. (2013). Impact of National Horticulture Mission on its beneficiaries. International Journal of Exten. Edu. (9), pp: 72-80.

\section{How to cite this article:}

Dhulgand, V. G. and Kadam, R. P. 2019. Socio-Economic Impact of Mahatma Gandhi National Rural Employment Guarantee on its Beneficiaries in Marathwada Region. Int.J.Curr.Microbiol.App.Sci. 8(12): 1808-1820. doi: https://doi.org/10.20546/ijcmas.2019.812.217 